\title{
Japan, China and East Asian regionalism: implications for the European Union
}

\author{
Christopher M. Dent
}

Published online: 30 October 2008

(C) Springer-Verlag 2008

\begin{abstract}
East Asia is becoming an increasingly coherent regional entity in political economic terms, and remains a region of enormous geo-strategic significance for the European Union. Europe's links with China and Japan are especially important, and moreover these two countries are looking in various ways to exercise various forms of regional leadership in East Asia. This has critical implications for the EU's relations with the East Asia region generally, and also for the wider international system. Similar and related impacts maybe construed from deepening East Asian regionalism, involving processes where both Japan and China play vitally important roles. The analysis presented here examines the both micro and macro level developments in East Asian regionalism, and issues relating to Japan, China and regional leadership. It concludes by discusses the implications of these matters for the European Union, and recommends that the EU should pay particularly close attention to emergent exercises of regional leadership in East Asia, most likely to be performed by Japan and/or China.
\end{abstract}

\section{Introduction}

The East Asia region has become one of enormous geo-strategic significance for the European Union, especially in economic terms. EU trade, investment and financial linkages with East Asian countries have grown rapidly over the last few decades, and the EU-East Asia economic partnership is one of the most important in the global economy (Dent 1999). The European Union's economic relations with East Asia have deepened not just because of East Asia's phenomenal economic growth rates but also due to the region's fast developing international economic integration at both the micro and macro levels. East Asian regionalism and regional community-building have made great strides, especially since the region's 1997/98 financial crisis, an event that spurred the region's states into closer diplomatic and policy co-operation arrangements with each other in matters of finance, trade and other economic-related issues. The

C. M. Dent $(\bowtie)$

Department of East Asian Studies, University of Leeds, 14-20 Cromer Terrace, Leeds LS2 9JT, UK

e-mail: c.m.dent@leeds.ac.uk 
formation and progress of the ASEAN Plus Three regional framework has been particularly important in this regard, leading to new schemes of regional financial governance and transnational issue management. Running parallel to this has been the region's new free trade agreement trend, which has been primarily bilateral in nature. As the region's associative, integrational and organisational coherence has developed (Dent 2008a), so has its capacity to be 'led'. This paper will discuss the prospects for Japan and China exercising regional leadership in East Asia, and how this may impact upon the EU's dealings with the region.

\section{Micro-level developments in East Asian regionalism}

Regional integration has been an important functional aspect of East Asia's dynamic economic development over the last four or five decades. For most of this period, this particularly relates to integrational coherence forged at micro-level (i.e. firms, other private / civil society organisations, individuals), and here primarily concerning the expansion of multinational enterprise (MNE) activity. Japan played an initial leading role on this front, its keiretsu MNEs developing international production network (IPNs) arrangements that over time encompassed a growing number of other East Asian countries into regionalised divisions of labour. Figure 1 indicates how Toyota currently operates such a system of regionally integrated production, trade and

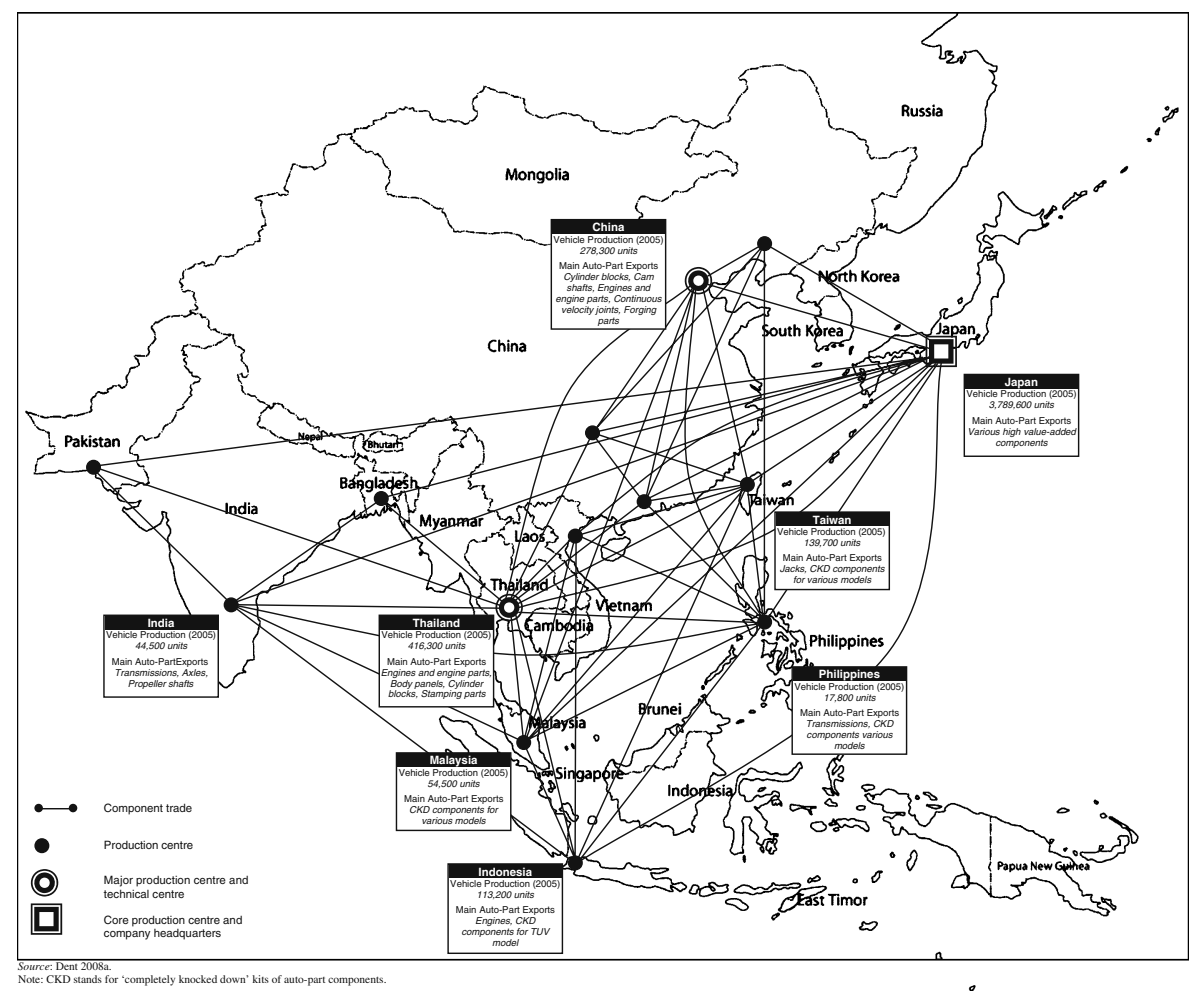

Fig. 1 Toyota's Asia international production network in 2006 
investment, what may be referred to as a comprehensive regional production network. MNEs from other countries operate in a similar fashion in East Asia concerning the region's most important industrial sectors - electronics, machinery, automobiles, transport equipment, and information and communications technology (ICT) - that together account for about $80 \%$ of the region's total trade. These sectors produce multi-component goods, the manufacturing thereof fragmented into various subassembly production operations with production situated in the most advantageous locations around the region. In no other region in the world is regionalised IPN activity so developed or extensive (Ando and Kimura 2003; Borrus et al 2000). The World Bank (2003) calculated that by the end of the 1992-2000 period, international

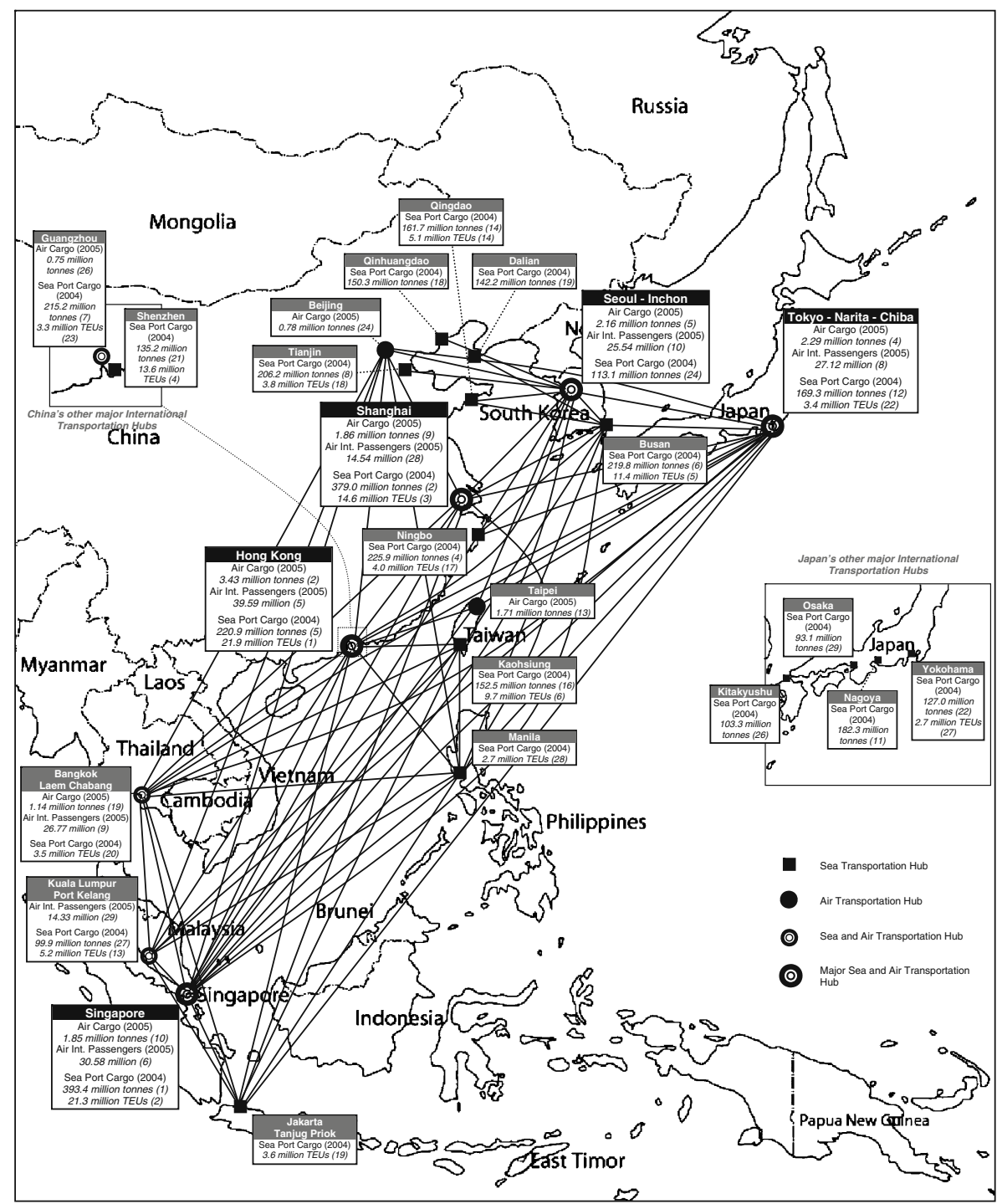

Fig. 2 East Asia's main regional transportation hubs and corridors 
trade in components and parts accounted for 33\% of East Asia's total intra-regional export trade, higher than North America's 25\% and the EU's 20\%.

Not only has IPN activity helped raise East Asia's overall intra-regional trade ratio from $35 \%$ in 1980 to $55 \%$ by 2005 (which compares to the EU's $65 \%$ and North America's 45\%) but more importantly IPN arrangements have made trade, production and investment links more functionally integrative (Dent 2008a). This micro-level regionalisation of the East Asian economy has been assisted by the parallel development of regional infrastructure networks based around transportation and communication hubs. Figure 2 shows how these have acquired regional significance, revealing the dense channels and flows of economic exchange within the region. In sum, the regionalisation of trade, production and infrastructural linkages operate at a high level of functional integration in comparative regional terms.

\section{Macro-level developments in East Asian regionalism}

\section{Introduction}

These concern regional integration that arises at the country or 'whole economy' level as a result of international economic agreements. This has been a relatively new development in East Asian regionalism. By the mid-1990s, the only free trade agreement (FTA) signed in the region was the Association of Southeast Asian Nations (ASEAN) Free Trade Area, or AFTA, and the core of this was not operationalised until 2003. No other FTA had been signed by an East Asian country by the mid-1990s, nor any other bilateral or regional economic agreement of significance within the region itself. While ASEAN countries were meeting regularly by this time to discuss Southeast Asian regional economic affairs, no exclusive East Asian regional grouping had been forged. This was all to change after the region's 1997/98 financial crisis.

The impact of the 1997/98 financial crisis and the ASEAN Plus Three framework

The crisis exposed both the deep extent of regional economic interdependence in East Asia as well as the lack of regional-level coping mechanisms to deal with international economic crises. In organisational terms, East Asian countries used the newly inaugurated ASEAN Plus Three (APT) framework to develop new regional financial governance mechanisms. The APT regional diplomacy framework consisted of the ten ASEAN member states plus China, Japan and South Korea, and its first meeting was held in December 1997. Japan took the initial lead in constructing preliminary financial co-operation agreements, such as the New Miyazawa Initiative launched in 1998 that was later to evolve into the region-wide Chiang Mai Initiative (CMI) network of bilateral currency swap agreements, first formed in 2000. By May 2008, the CMI system had expanded to 16 bilateral agreements with the sum total of US\$85 billion. At the time, APT Finance Ministers agreed to convert these bilateral arrangements into a multilateralised system that would create a common funding pool of foreign exchange reserves from which CMI members could draw upon in times of crisis. Depending on how substantially the 
new multilateralised CMI is developed, it could play a key role in establishing a regional exchange rate system, another idea that has been raised in APT meetings and studied by some East Asian governments, especially Japan.

With the help of the Asian Development Bank (ADB), the APT framework also launched the Asian Bond Market Initiative (ABMI) in 2003. Like the CMI, the ABMI provides East Asia with the opportunity to utilise the region's huge financial resources for promoting its own regional financial stability and economic development, rather than investing in, or diverting these resources to other regions or countries. East Asia not only has huge foreign exchange reserves but also very high levels of domestic savings, at around 30 to $40 \%$ of GDP. A large proportion of the region's financial resources have over time been invested in bonds and other securities originating outside the region, especially in advanced industrial countries like the United States. East Asia's own capital markets have generally been slow to develop, with only higher income countries like Japan and South Korea having established credible markets for bonds. Moreover, Asian currency-denominated bonds were not internationalised. For example, by 2004 only 4\% of Japanese government bonds were held outside the country in $2004 .^{1}$ The ABMI has thus sought to rectify the above by gradually strengthening East Asia's long-term financial market development. In this sense, the ABMI may be considered more strategic in conception than the CMI, as it moves East Asia beyond measures simply aimed at crisis-aversion towards building more substantive financial market integration in the region (Dent 2008a).

\section{The East Asia Summit}

At the 2000 APT summit held in Singapore a proposal was made for establishing an East Asia Summit (EAS) framework that would in effect transform the APT into a more coherent and developed regional framework in which any APT member could host a summit, not just an ASEAN country. The EAS also embodied a more holistic regional concept and not just an appendage arrangement to ASEAN, as many still view APT. A further perceived advantage of the EAS over APT was that it would potentially confer China, Japan and South Korea a greater sense of ownership over the East Asia regional community-building process. It was initially believed that the APT would simply evolve into the EAS, subsuming all its work programmes and adopting its framework structure. This was the general understanding that prevailed right up until the November 2004 APT Summit. ${ }^{2}$ However, what transpired was the EAS becoming neither a substitute for the APT nor a distinctly separate mechanism in its own right during the mid-to-late 2000 s period. The main underlying reason for this is that EAS membership not only comprises the APT group but also - at primarily Japan and Indonesia's insistence-India, Australia and New Zealand. The first East Asia Summit was held in December 2005, hosted by Malaysia at Kuala Lumpur, and much of the discussion at the meeting revolved around membership

\footnotetext{
${ }^{1}$ Business Times Singapore, 24.05.2004.

${ }^{2}$ Associated Press, 29.11.2004.
} 
issues and what value the EAS framework could add to the regional communitybuilding process beyond what was already being achieved by the APT.

It was generally believed that Japan's strategic interest in broadening the membership of the EAS was to add greater counterweight to an ascendant China in any emerging East Asian regional organisation or framework. However, as we later note, Japan's predilection for a broad East Asian grouping pre-dates the EAS issue (Hund 2003). In the mid-1990s, Tokyo had advocated the inclusion of Australia and New Zealand in the Asia-Europe Meeting (ASEM) framework. China, Malaysia and others on occasion, though, have argued for a more conventional East Asian grouping. ${ }^{3}$ At the inaugural East Asia Summit, hosting Malaysian Prime Minister Abdullah Badawi commented in relation to the grouping that, "You are talking about a community of East Asians. I don't know how the Australians could regard themselves as East Asians, or the New Zealanders for that matter", and inferred that the main architects of the EAS process should be the 'core' APT member states. ${ }^{4}$ His predecessor, Mahathir Mohamed, also questioned why Australia and New Zealand should be permitted to join the EAS because they are essentially Oceanic countries with limited socio-cultural linkages with East Asia (Mahathir 2006).

Free trade agreements and East Asia

Debates over the constituent membership of an East Asian community have crossed over to discussions on establishing a regional FTA amongst 'East Asian' states. Ideas for creating an East Asia Free Trade Agreement (EAFTA) have been discussed at APT meetings and in other fora. The formation of an EAFTA was one of the key recommended long-term objectives made in the APT sponsored East Asia Study Group report (EASG 2002). However, it was not until 2006 that such a proposal was formally made within the region. This originated from Japan and was announced in April of that year, being conceived as an EAS-based FTA and officially known the Comprehensive Economic Partnership for East Asia (CEPEA). ${ }^{5}$ When launching the initiative, Japan's then Economic Minister, Toshihiro Nikai outlined a plan to commence CEPEA negotiations in 2008 and concluding them by 2010. The plan met with general scepticism, especially with respect to the relatively short time scales involved. In response, Nikai announced a revised CEPEA plan in August 2006 that included funding to help start the negotiation process and to create an East Asia Economic Research Institute for ASEAN and East Asia in an ASEAN country that would undertake facilitating research in support of the regional FTA project.

Some support for the initiative slowly mounted. India, New Zealand and Australia showed immediate and positive interest, while ASEAN's Secretary-General, Ong Keng Yong commented that it could be achieved within 10 years. ${ }^{6}$ ASEAN member

\footnotetext{
${ }^{3}$ For example, Thailand and the Philippines, along with Malaysia, were more inclined to support China's APT-based regional FTA idea than Japan's EAS-based alternative.

${ }^{4}$ Japan Times, 22.12.2005.

${ }^{5}$ The CEPEA proposal was contained within a report published in April 2006 by Japan's Ministry of Economy, Trade and Industry entitled 'Japan's Global Economic Strategy' (METI 2006).

${ }^{6}$ All Headline News, 08.08.2006.
} 
states, on the other hand, were still generally pessimistic as to the feasibility of the idea by November. ${ }^{7}$ China and South Korea was also sceptical, especially China, which thought Japan's EAS-based proposal may have been primarily motivated as a means to outflank China's long-term influence within the East Asia regional community. In a similar vein, the US's push for a Free Trade Area of the AsiaPacific (FTAAP) in the lead up to the November 2006 APEC Summit was viewed as largely in reaction to Japan's CEPEA proposal (Dent 2007). An exclusive East Asia FTA could potentially marginalize American commercial interests in the region. To allay US anxieties on the matter, Japan suggested that the CEPEA would be a building block for a larger Asia-Pacific agreement. ${ }^{8}$

As the Second East Asia Summit approached, Tokyo intensified its diplomatic efforts to build coalitional support for its CEPEA proposal. A number of ASEAN member states (e.g. Singapore, Indonesia, Vietnam) came on Japan's side, and South Korea also became more positively inclined towards the idea. At the regional meeting, held in Cebu, Philippines in January 2007, Japan secured enough support for an agreement to undertake feasibilities studies into the CEPEA, these commencing in March that year and the report from which would be submitted at the next East Asia Summit.

While Japan has championed an EAS-based regional FTA, China is more in favour of an APT-based alternative, i.e. not including India, Australia or New Zealand. These contrasting views first came to light at the inaugural East Asia Summit meeting held in December 2005. Malaysia, Thailand and the Philippines were more inclined to support China's views on this than Japan's but neither was able to build enough support then to prevail over the other. Even though Japan's CEPEA idea seemed to achieve this at the Second EAS meeting, there was no consensus then on whether the group should necessarily proceed to negotiations. A decision on this may be deferred to a future EAS meeting.

China's case for an APT-based FTA is founded on the argument that the ASEAN Plus Three group is more economically, socio-culturally and to some extent politically coherent than its EAS counterpart. Whilst India, Australia and New Zealand (hereafter referred to as the EAS-3) have developed closer economic ties with APT countries over recent years - including through the signing of bilateral FTAs — they have remained largely peripheral to East Asia's regional economic dynamic, for example in terms of international production network development. The Asian Development Bank has made a similar argument regarding APT-based rather than EAS-based financial regionalism (Dent 2008b). Moreover, EAS-3 approaches to economic governance (e.g. Australia and New Zealand's market-liberal capitalism) are in some contrast to the developmental statist approach still followed by many East Asian countries. This is relevant to the ideational differences between Anglo-Pacific countries and East Asian countries on FTA formation, where the latter have a predilection for incorporating economic co-operative measures in their agreements and the former do not.

Furthermore, no doubt one reason why Japan wanted the two developed countries of Australia and New Zealand included in their CEPEA proposal was to broaden a base of support to include more commercial regulatory measures (e.g. IPR,

\footnotetext{
${ }^{7}$ Kuna News, 02.11.2006.

${ }^{8}$ Vietnam News, 14.11.2006.
} 
competition policy) into any future regional agreement. China and many ASEAN countries will resist too much priority being conferred to this area. These could be real problem issues in any future CEPEA negotiations. Yet as the bilateral FTA experience has shown, the biggest challenge for any future EAFTA talks - whether APT or EAS group based - is likely to be agriculture. Many East Asian countries retain highly protected agricultural sectors whilst for many other countries farm products still account for a substantial share of their exports. Reconciling differences on this highly sensitive political issue is crucial to establishing a regional free trade agreement in East Asia.

The idea for creating a regional FTA in East Asia, however its constituent membership is conceived and eventually agreed upon, has derived from the expansion of primarily bilateral FTA activity within East Asia and the Asia-Pacific since the 1997/98 financial crisis (Dent 2006; Okamoto 2003; Ravenhill 2003) see Fig. 3. In addition to AFTA, a number of bilateral and quasi-regional FTAs have been signed amongst East Asian countries since this time - see Fig. 4. While the region's leaders have talked of how the increasingly dense pattern of FTA activity is making a positive contribution to regional community-building, there is an equal chance that the trend is having an opposite effect. Free trade agreements are essentially preferential and heterogeneous, each establishing its own distinct set of rules on international trade, investment and commercial regulation. Unlike in the EU case, there is no discernable 'FTA model' in East Asia, rather sets of generally competing models (i.e. Japan-centred, China-centred, ASEAN-centred) and a situation of 'structured preferentialism' at the macro-level of East Asian regional trade. While quasi-regional agreements such as the ASEAN — China FTA (ACFTA) and Japan - ASEAN Comprehensive Economic Partnership (JACEP) have helped avert too much spaghetti being thrown into the East Asia's trade bowl, and there is

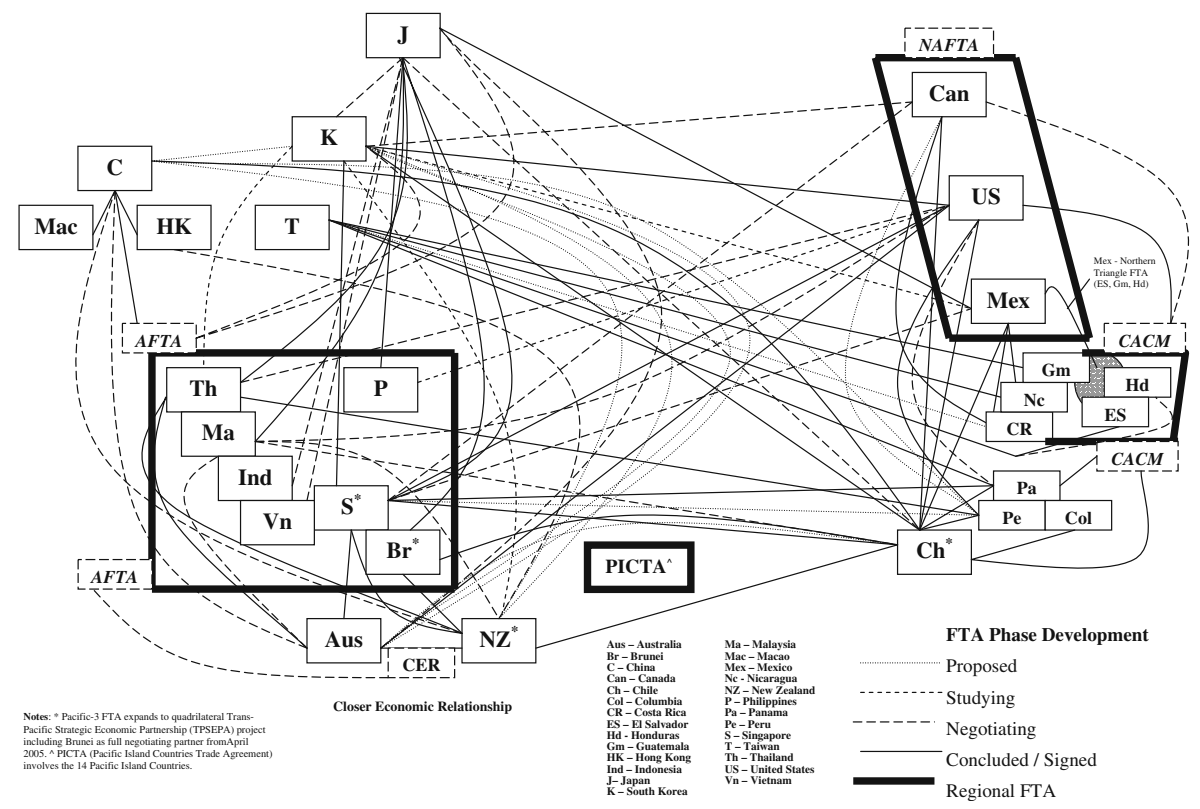

Fig. 3 Asia-Pacific FTA projects (by June 2007) 


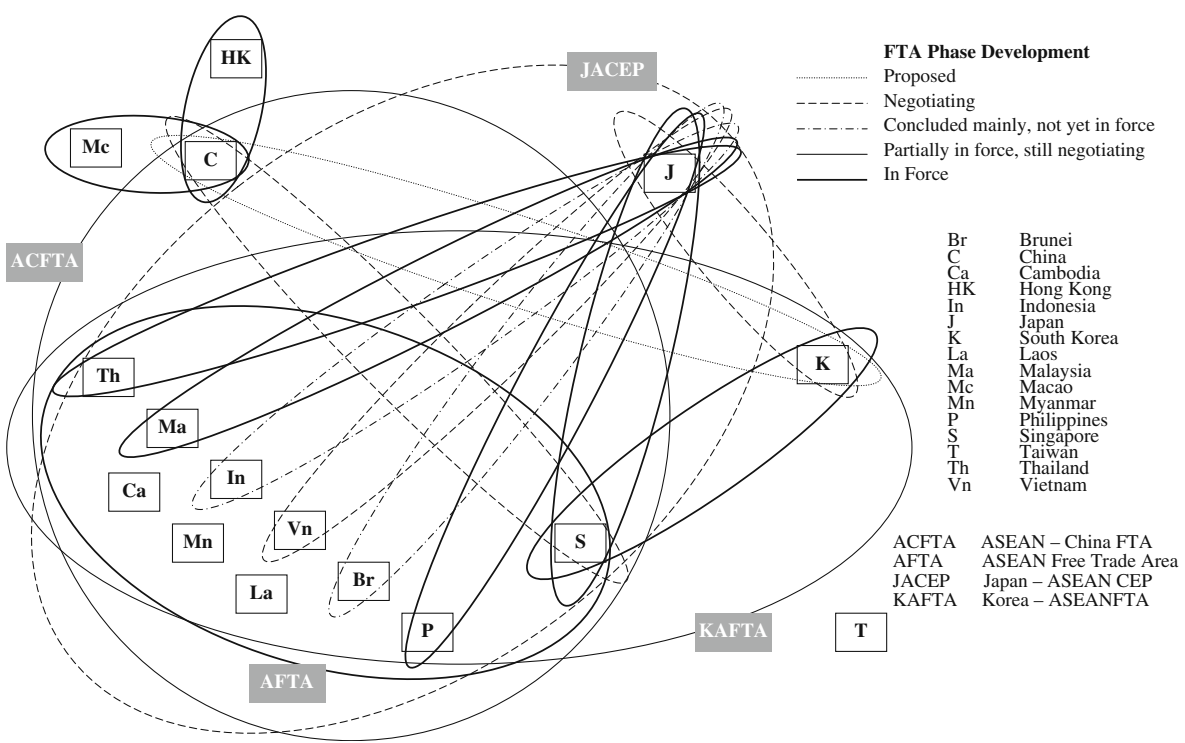

Fig. 4 FTA linkages within East Asia (by June 2007)

also some commonality in ideational approach to FTA formation in East Asia around the 'economic partnership' principle, the region is nevertheless left with the difficult challenge of trying to reconcile multifarious politico-economic and business interests embodied within already signed FTAs when negotiating a whole new and superseding regional agreement. The most important of these interests are championed by either Japan or China, and therein lays the most critical challenge. Their differences over commercial regulation issues (e.g. intellectual property rights) and agriculture alone pose enormous obstacles to realising a regional trade deal. If negotiations are eventually initiated, concluding an agreement is likely to take many years.

\section{Japan, China and Regional leadership in East Asia}

East Asia’s evolving regional political economy

Bound up in East Asia's regional community-building process is the key issue of which power (or configuration of powers) best qualifies as East Asia's regional 'leader' or 'hegemon'. Japan was initially the obvious first choice given its early economic pre-eminence. Yet, a number of inter-related factors conspired against it assuming positions of overt regional leadership. First, Japan's close relationship with the United States has orientated many if not most core aspects of Japan's foreign policy to US geo-strategic interests, including maintaining America's dominance of the Asia-Pacific's security arena. This helps explain the second factor, namely Japan's hitherto long-standing preference of fostering a Pacific economic community rather than an East Asian equivalent. From the 1960s, Japan has worked with Australia and later with the other US security partners, and the US itself, to develop 
Asia-Pacific diplomatic frameworks towards this end. It was, for example, Japan that first proposed the idea for a Pacific Free Trade Area, or PAFTA, comprising the trans-region's main Cold War allies of Japan, the US, Canada, Australia and New Zealand (JERC 1966). Japan and Australia were also the principal architects of the track II diplomatic processes that culminated in the establishment of the Asia-Pacific Economic Co-operation (APEC) forum in 1989 (Korhonen 1994). Third, Japan's associative ties with other East Asian countries - especially in political, security and even socio-cultural terms - were weak. Japan considered itself strongly aligned to Western powers (e.g. through G7 membership) and saw itself as somehow separate from East Asia, being an island power with strong global connections. Some similarities between Britain and continental Europe may be drawn here. Fourth, Japan either was not able or had no interest in converting its considerable economic power into the geopolitical currency required to secure positions of regional leadership (Drifte 1996).

The above generally applies to the Cold War period. Japan now views East Asian regional community-building and the closely associated matter of regional leadership in quite a different light (Samuels 2007). This turnaround maybe also explained by a series of inter-related factors. First, Japan felt somewhat culpable for the 1997/98 financial crisis and was sufficiently resourced in both financial and technocratic terms to exercise leadership on finding future crisis-aversion solutions, as previously detailed (Katada 2002). Second, East Asia has subsequently become a far more coherent region to lead over the last decade or so, particularly after the formation of the APT framework and the willingness of East Asian countries to enter into more substantive international (economic) agreements. Third, all East Asian countries recognise that their common region faces a set of increasingly significant regionwide challenges that are best addressed at the regional level. These include energy security, food security, environmental degradation, trans-boundary pollution, development asymmetry, international migration, maritime piracy, terrorism, and pandemic outbreaks such as SARS and avian flu. Some form of regional leadership is often required to tackle such problems arising across the region. Fourth, Japan has at the same time had to come to terms with the seemingly inexorable ascendance of China. From a broader and historic perspective, this is the first time in a very long time that both countries hold simultaneous positions of international strength. Hence, China and Japan have had to reformulate their positions towards, and conceptions of the other in diplomacy and strategic policy terms.

\section{The Sino-Japanese relationship}

More generally, the Sino-Japanese relationship is of critical importance to the future of East Asian regionalism. Japan and China are the region's two great powers, and together they account for almost $80 \%$ of East Asia's GDP. Without either one of these countries, East Asia's impact on the international system would be considerably diminished. But how have Sino-Japanese relations developed over recent years? On the one hand, their destinies have become increasingly interlinked through growing economic interdependence and the deepening integration of the East Asia region generally. There is also an expectation from other East Asian countries for both China and Japan to take a lead on regional-level affairs (Dent 
2008c; Rose 2004). Sino-Japanese relations however remain problematic owing to a combination of unresolved historic issues and the potential for regional hegemonic rivalry between the two countries.

If China manages to sustain its staggering economic momentum then it will enjoy certain strategic advantages over Japan. This is because it will offer dynamism (e.g. fast expanding commercial opportunities) with an economy many predict will be bigger than Japan's in the not too distant future. China is also able to play a more comprehensively proactive role in international affairs, especially in conventional security matters as Japan is encumbered by certain constitutional constraints in this area. For example, China is a permanent member of the United Nations Security Council, and it is Beijing not Tokyo that hosts the Six Party Talks on North Korea's nuclear programme. China has also been busy fostering closer security ties with a number of Asian countries and, arguably, has played a more proactive role in multilateral institutions over recent years. Yet Japan has an essential role in the region's future, and the advancement of East Asia's regionalism is to a large extent dependent on an effectively working Sino-Japanese partnership.

Taking first recent developments in Japan - China economic relations, both have become vitally important trade partners to each other. By 2005, their bilateral trade was approaching US\$200 billion per annum. Japan has become a crucial source of foreign capital and technology for China, and China a critically important production base for many of Japan's multinational enterprises. By 2004, Japanese companies had invested around US\$56 billion in China covering almost 28,000 projects. Japan is also China's largest source of overseas development assistance (ODA) accounts for around half the loans it received from foreign governments. ${ }^{9}$ However, the amount of Japanese ODA given to China has been steadily falling and a growing number of trade disputes have arisen between the two countries, e.g. over certain agricultural and textile products.

At the same time, new forms of dialogue and co-operation established at the Northeast Asian sub-regional level have helped China and Japan resolve such disputes and moreover place their economic relations on a more positive footing (Aggarwal and Koo 2005). China - Japan - South Korea trilateral summits have been held since 2000. Corresponding trilateral meetings of Economic and Foreign Ministers have followed, as well as new dialogue frameworks at a lower government level and various track II initiatives, such as studying the feasibility of creating a Northeast Asia Free Trade Area. ${ }^{10}$ At the 2003 Northeast Asia summit, the three countries agreed to substantially expand their co-operation across a range of fields, including on security, trade, investment, technology, environment, human resource development and energy security issues. ${ }^{11}$ At the Seventh Trilateral Summit held in January 2007, plans were announced to start negotiations on a trilateral investment treaty later that year, and also establish a mechanism of regular consultations among

\footnotetext{
${ }^{9}$ People's Daily, 05.01.2004.

${ }^{10}$ The Chinese Development Research Centre of the State Council (DRC), the National Institute for Research Advancement (NIRA) of Japan and the Korea Institute for International Economic Policy (KIEP) published a joint scoping study report on the NEAFTA idea in November 2003. (Asia Times, 20.11.2003).

${ }^{11}$ Financial Times, 07.10.2003.
} 
senior foreign affairs officials of the three countries. ${ }^{12}$ Japan, China and South Korea furthermore agreed to further extend the scope of their trilateral co-operation, naming a number of new priority areas including finance, public health, tourism, logistics and distribution, youth and teenager communications. The three countries also agreed to hold annual trilateral Environment Ministers meetings in the future.

In addition to APT, EAS and APEC, these new forms and structures of cooperative economic diplomacy are helping establish a firmer foundation on which a Sino-Japanese partnership can be developed, and therein the basis of their coleadership in East Asian regional affairs. Yet Japan has found it particularly hard to gain the trust of other East Asian nations with regard to adopting a regional leadership role. The past horrors of Japanese imperialism remain in the memories of many of East Asia's older generations. Continued visits made by the country's top political leaders, most notably Prime Minister Junichiro Koizumi (in office 20012006), to the Yasukuni Shrine — amongst its honoured war dead of around 2.5 million Japanese (over the 1853-1945 period) are over 1,000 Second World War criminals, including fourteen convicted Class-A criminals - has angered many Chinese and other East Asian peoples. The issue of Japan's school history textbooks has further compounded the problem. According to its critics, the textbooks present a distorted view of Japanese military practices in East Asia during the Second World War. A renewed sovereignty dispute arising in 2005 between Japan and South Korea over the Dokdo / Takeshima Islands has also made other East Asian countries somewhat wary of rising nationalist sentiments in Japan. However, the same countries are concerned too about the growing sense of nationalism within China's society. Moreover, reconciling nationalism with regional community-building is a fundamental challenge that is relevant to many parts of East Asia.

While these disputes and acrimonious issues have simmered, Japan has demonstrated an interest in acting as a benefactor to the region as a whole, and therein attempting to build trust with other East Asian countries. Japan's ODA programme has made an important contribution to the economic development of the region's poorer nations since the 1960s (Yoshimatsu 2003). As was discussed with the 1997/98 financial crisis and APT diplomacy, Japan has too been willing to dedicate considerable financial and technocratic resources to improving East Asia's regional financial governance structures. Japanese diplomacy concerning the 2004 Asian Tsunami disaster was also revealing. Tokyo reacted quickly to the crisis, offering US\$30 million of humanitarian aid just a few days after the disaster struck, which was double the initial US offer of financial assistance. After the US raised its offer to US\$350 million, and China announced its own contribution of US\$63 million, Japan then quickly upped its offer to US\$500 million (representing a quarter of the world's total pledge), keen to show that it was a dependable and generous partner on matters of great regional importance. Many though interpreted this counter-move as being motivated more by diplomatic rivalry rather than humanitarian concern, for example Japan offering an aid package that could not easily be matched by China at such short notice. Japan's financial diplomacy has proved a key instrument when the country has sought to practice regional leadership, and China

\footnotetext{
12 Associated Press, 11.01.2007.
} 
has at times been somewhat wary of this. For example, China was concerned that the proposed Asian Currency Unit scheme - championed by Japan mainly through ADB channels - would be dominated the Japanese yen if the weighting criteria advocated by Japan were to be used (Dent 2008c).

At the January 2005 conference of major tsunami aid donors and relief organizations held in Jakarta, Japanese Prime Minister Junichiro Koizumi and Chinese Premier Wen Jiabao reportedly could barely manage a few pleasantries when they walked past each other on the conference main stage. ${ }^{13}$ A similar scene played out at the inaugural East Asia Summit held later that year, and the differences in opinion between Tokyo and Beijing over the EAS membership issue was noted in the main text. Relations between the leaderships of both countries had been strained around this time owing to aforementioned reasons, e.g. Yasukuni Shrine visits by Prime Minister Koizumi. In addition to this, China was refusing to back Japan's application to become a permanent member of the UN Security Council, and Japan likewise opposed China's bid to accede to full membership of the G8 group.

High-level Sino-Japanese relations began to thaw somewhat, however, when in October 2006 newly elected Japanese Prime Minister Shinzo Abe made the first visit to Beijing by a Japanese premier in many years. ${ }^{14}$ A new positive trend in SinoJapanese relations has continued thereafter. In making a reciprocal visit to Tokyo in April 2007, Chinese Premier Wen Jiabao made an historic speech to the Japanese Diet - the first ever given by a Chinese premier — in which Wen recognized Japan's apologies for its aggression in Asia and called on both countries to reconcile their differences. He furthermore highlighted China and Japan's deepening economic interdependent relationship and how closer co-operation was in the long-term interests of both countries. ${ }^{15}$ Japan's more recent Prime Minister, Yasuo Fukuda, made improving his country's relations with China a foreign policy priority. In May 2008, Hu Jintao made a state visit to Japan, the first Chinese President in over a decade to do so, and reiterated China's interest in enhancing co-operation between both countries. Prime Minister Fukuda replied in kind, proclaiming that both China and Japan shared larger responsibilities for the world's peace and development in the 21st Century. Notwithstanding these positive developments, there remain a number of long-standing and relatively new issues need to be addressed in Sino-Japanese relations if East Asian regionalism is to advance substantially over forthcoming years and decades. As we have already discussed, one of the most important of these concerns the different views and interest each country has regarding the constituent membership of any emergent East Asia community.

\section{Addressing regional leadership}

So how will both Japan and China, and indeed other East Asian states, address the issue of East Asian regional leadership? There are a number of possible generalised outcomes to consider from the 'macro-state' perspective: that is based on whole nation-state engagement from an agency or actor level viewpoint. First, Japan and

\footnotetext{
${ }^{13}$ China Daily, 31.01.2005.

${ }^{14}$ Yomiuri Shimbun, 23.10.2006.

15 Japan Times, 13.04.2007.
} 
China may openly contest leadership of the East Asia region, which carries the risk of adverse competition effects, and the strong possibility of one seeking to cancel out the other's bid(s) for leadership. A second option is for both countries to come to tacit or explicit agreements on the division of labour concerning regional leadership - for example, Japan on finance and technology, China on security - or through different fora, e.g. WTO, IMF. There are 'fungibility of power' issues to consider here, as there may be spillovers of power and influence from certain domains into others, such as economic into politico-military security or vice versa. A third option is general co-leadership, where China and Japan form a broad alliance, akin to France and Germany in the EC / EU, centred on further advancing East Asian regionalism and representing East Asia in multilateral fora. This is contingent, however, on the development of stronger and more harmonious Sino-Japanese relations.

China and Japan may instead, though, opt for alternative co-leadership arrangements with other East Asian states, e.g. South Korea, Indonesia, Malaysia. A further option is for coalitional leadership whereby Japan and China exercise regional leadership through different sub-set coalitions of East Asian states on particular issues, as has been demonstrated on the APT versus EAS based regional FTA proposals noted earlier. From a slightly different perspective, a situation of group consensus leadership may arise in which neither China or Japan emerge as distinct regional leaders but rather leadership is exercised by group collective action (consensus-based, decentralised bargaining) through regional organisations and frameworks such as APT and EAS. Finally, there is the possible null leadership outcome, where no clear regional leader or leadership structure emerges in East Asia owing to various reasons. This may arise for instance where China or Japan opt to avoid exercises of regional leadership, or where China and Japan seek to cancel out the others bid for a regional leadership position.

Generally speaking, it is useful and relevant generally, though, to consider the plurality of co-existing exercises in regional leadership rather than singularity of regional leadership status. This may be apparent at various levels of actor (e.g. government, individual political leader, elite decision-making groups), in different forms of governance (i.e. any governance structures that link regional actors), different issue domains (e.g. finance, humanitarian relief, security), and at different geo-spatial scales (e.g. micro-regional, macro-regional), these all relating to what may be referred to as the multi-agency and multi-structure nature of regional leadership (Dent 2008c).

Furthermore, Japan and China's proclivity for aspiring to regional leadership is dependent upon their alignments of identity and association with the East Asia region itself. For example, it was briefly noted earlier that Japan may consider itself more as an associate member of the West owing to its advanced industrial statehood, long-standing membership of the G8, and close ties with the United States. Meanwhile, China may develop a stronger alignment of identity and association with the developing world community generally. As both China and Japan are increasingly engaging with global governance issues, both countries may seek to exercise leadership at the global as well as at the regional level. Thus, regional leadership may not arise easily when potential or actual leaders have stronger alignments of identity and association elsewhere in the international system. In sum, regional leadership in East Asia may only arise if Japan or China identify strongly with, or at least associate themselves with an East Asia regional community. 
Then there is the issue of what styles and modes of regional leadership China and Japan are likely to adopt in the future, and this has significant implications for those both inside and outside the East Asia region. Where Japan or China's leadership behaviour may be construed as hegemonic, it may differ from the 'overt hegemonic' approach of the United States, i.e. a more assertive exploitation of a dominant position. Leadership and hegemony are treated more or less as synonymous terms in the mainstream literature on international leadership, primarily because of the empirical bias towards the United States. A distinction should, however, be made between the two concepts: hegemony is essentially one of power status (i.e. domination, control, supremacy), and invariably conceived as a proxy for dominance or for a preponderance of power. It thus follows that hegemonic actions may be generally interpreted as assertive or even coercive exercises of leadership. Yet hegemony is not the only basis on which leadership is exercised. Leader actors may be averse to exploiting their 'hegemonic' power and supremacy through singular or independent acts, instead working more in cooperation, conjunction or consensus with others, as a regional leading partner.

China's political leaders have advanced the notion of the country's 'peaceful rise' and 'peaceful development', which entails acting as a 'responsible' member of the regional and global community rather than as an explicit leader (Suzuki 2007). This may, though, be considered a diplomatic strategy to mitigate fears of an assertive China (Kurlantzick 2007; Tanaka 2006; Zhao 2004; Zheng 2005). Japan's 'stealth' or 'quiet' leadership approach has arisen out of similar imperatives (Drifte 2003; Hook et al 2005; Katada 2002; Pyle 2007; Samuels 2007). Both countries must deal with historical legacies (e.g. memories of Japan's past aggressive imperialism, and fears of a reborn Chinese tributary system), and their own strategies on 'ascendant threat' mitigation. However, their apparent common reluctance to pursue more explicit forms of regional leadership does not negate the de facto exercises of leadership associated with the various acts of a regional power behaving in a 'responsible' manner. Indeed, the idea of a regional power that is willing to take on responsibilities at the regional level may be considered as a communal approach to leadership.

The above is linked to the close relationship between regional leadership and regionalism, or regional-multilateralism. As we have seen, regional-multilateralism is one of if not the most important means by which both China and Japan generally are currently exercising regional leadership. Both countries' contribution to promoting new regional organisations and frameworks and regional communitybuilding processes generally has provided Japan and China the opportunity to demonstrate their 'responsible' regional leadership credentials (Katada 2002; Wong and Chan 2003). Hence, there exists an emerging inter-constitutive and codeterminant relationship between regional leadership and regional-multilateralism. Deepening regional-multilateralism in East Asia is creating new opportunities for the exercise of regional leadership generally. The APT and EAS frameworks have augmented the governance dimension under which regional leadership may arise, as well as helped delineate issue domain areas (through agenda-setting and programmatic action plans) and geo-spatial dimensions (through constituent membership) which in turn brings greater focus to the question of where regional leadership efforts should be directed. 
Similarly, exercises of regional leadership can make significant contributions to the development of regional-multilateralism, as well as the likely extent of contested regional-multilateralism between Japan and China, for example regarding their differences over core membership of an East Asian regional community (Zhao 2004). Each country is developing leadership diplomacy in different regional groupings, especially China in a quasi-regional grouping with Southeast Asia (ASEAN) and with Central Asian states through the Shanghai Co-operation Organisation. Japan has, in comparison, been slow to develop these kinds of links, although its micro-regional linkages at the sub-national level are relatively well developed (Jain 2006).

\section{Conclusion - Implications of deeper east asian regionalism for Europe?}

Deepening East Asian regionalism has major implications for the international system. We now consider these with particular reference to Europe. From the microlevel economic perspective, European MNEs have both contributed to and benefitted from deeper East Asian integration in terms of productivity and market access. China's growing engagement in the region's IPNs and other forms of transnational business activity has pulled in rising levels of foreign direct investment into the region, with a negative impact on European manufacturing employment levels in low to middle technology sectors. In addition, integration-derived competitiveness gains accrued to East Asia based firms and industries have exerted pressure on European manufacturing firms and workers more generally.

In macro-level economic terms, the growing number of FTAs signed by East Asian states has brought trade diversionary costs to EU commerce. Europe's FTA links with East Asia are minimal. Only the EFTA country group has signed agreements with East Asian countries (Singapore and South Korea), while the EU has thus far signed none. It had, however, initiated negotiations with South Korea in 2007 although problems soon arose after Seoul was reluctant to confer the same parity of preferences to the EU that it offered to the US in the Korea-US FTA deal struck in July 2007. The US only has one other FTA link in East Asia, this being with Singapore, and therefore the EU is not too far behind the US in terms of FTA-secured market access benefits. Yet countries from every other region in the world now have FTA links with East Asia, and the EU has been relatively slow off the mark. Europe's neglect has in one sense been laudable at a time when the recent intensification of (mostly bilateral) FTA activity has played its part in undermining attempts to secure a global-multilateral trade agreement, i.e. the WTO's Doha Round. The net welfare losses from the failure to realise a new multilateral trade deal are likely to be greater for Europe than those caused by an operationalised East Asia regional FTA.

This paper argued that the current prospects for initiating EAFTA negotiations do not look good, and this may remain the case for many years to come. What is perhaps more important for Europe to consider is East Asia's potential to become a regional financial power bloc rather than a regional trade bloc. It is financial regionalism rather than trade regionalism that have made the most substantive advances in East Asia at the macro-level over recent years (Dent 2008d). East Asian countries, along with the Asian Development Bank, have been examining ideas for 
exchange rate co-operation and co-ordination based on the conflation of a new multilateralised CMI system and a proposed Asian Currency Unit scheme (Dent 2008b). Europe needs to monitor such developments very carefully, especially when the role and even existence of the International Monetary Fund (IMF) is being called into question, and hence we are possibly entering a time when a reformulation of the global financial architecture may be anticipated.

In broader geopolitical terms, deepening East Asian regionalism and moves towards a multi-polar 'regional' world order generally is arguably more in the EU's long-term interest than that of the United States. As Hettne (2005) contends, such a regional world order more befits the EU's 'post-Westphalian' model of international (or rather inter-regional) relations than the US's 'neo-Westphalian' model of a singular superpower maintaining the international order. We may also view East Asia's regional community-building as part of a useful conditioning process for East Asian nations working more co-operatively with others, with positive effects for broader international community-building generally. This can only work to the EU's advantage in the long-term, especially with regard to its relations with China.

There are, however, potential geopolitical risks associated with deeper East Asian regionalism. It would further consolidate the tripolar world economic structure where three regions - Europe, North America and East Asia - continue to dominate the global economy and hence perpetuate core-periphery development and power asymmetries. The division of the international system into some kind of Orwellian three-bloc world seems unlikely, and as discussed earlier, China may align itself more closely with a coalition of other large developing countries (Brazil, India, South Africa - as already seen in WTO diplomacy) than with those in its regional neighbourhood. China is fast developing its 'global reach' capacity and this poses a quite different set of geopolitical challenges to Europe, as China's expansive foray into aid diplomacy in Africa demonstrates.

Finally, the European Union should pay close attention to emergent exercises of regional leadership in East Asia, most likely to be performed by Japan and/or China. With East Asia becoming a more coherent region in associative, integrational and organisational terms (Dent 2008a), so its capacity to be led or represented on the international stage will increase. East Asian regionalism is unlikely to follow the treaty-driven institutionalism of the EU approach, and different architectures of regional leadership and representation should be expected to arise. This paper has discussed some possible options here. If firmer structures and exercises of regional leadership do emerge in East Asia, then the calculus of EU diplomacy with the region could significantly change. For historic reasons, the EU's ties with East Asia have been strongest with the ASEAN group but ever greater priority will be afforded to Japan and/or China if either or both more clearly aspire to positions of regional leadership.

\section{References}

Aggarwal VK, Koo MG (2005) 'Beyond network power? The dynamics of formal economic integration in Northeast Asia’. The Pacific Review 18(2):189-216 
Ando M, Kimura F (2003) The Formation of International Production and Distribution Networks in East Asia, National Bureau of Economic Research Working Paper No. 10167, NBER, Cambridge MA.

Borrus M, Ernst D, Haggard S (2000) International production networks in Asia: rivalry or riches? Routledge, London

Dent CM (1999) The European Union and East Asia: an economic relationship. Routledge, London

Dent CM (2006) New free trade agreements in the Asia-Pacific. Macmillan, Basingstoke

Dent CM (2007) 'Full Circle? Ideas and ordeals of creating a free trade area of the Asia-Pacific' (2007). The Pacific Review 20(4):447-74

Dent CM (2008a) East Asian regionalism. Routledge, London

Dent CM (2008b) 'The Asian Development Bank and developmental regionalism in East Asia', (2008). Third World Quarterly 29(4):767-86

Dent CM (2008c) China, Japan and regional leadership in East Asia. Edward Elgar, Cheltenham

Dent, CM (2008d) 'New Regional Financial Agreements (RFAs) in East Asia: Beyond 'Trade-Oriented' Regional Integration and Co-operation', Inter-Asian Connections conference, US Social Science Research Council, Dubai, 21-23 February 2008

Drifte RFW (1996) Japan's foreign policy in the 1990s: From economic superpower to what power? Macmillan, London

Drifte RFW (2003) Japan's security relations with China since 1989. From balancing to bandwagoning? Routledge, London

East Asia Study Group (2002) Final report of the East Asia study group, East Asia Study Group

Hettne B (2005) 'Beyond the new regionalism'. New Political Economy 10(4):543-71

Hook GD, Gilson JA, Hughes CW, Dobson HJ (2005) Japan's international relations: politics, economics and security, 2nd edn. Routledge, London

Hund M (2003) 'ASEAN plus three: towards a new age of pan-east Asian regionalism? A Sceptic's View'. The Pacific Review 16(3):383-417

Jain P (2006) Forging new bilateral relations: Japan's sub-national governments in China'. In: Lam PE (ed) Japan's Relations with China: Facing a Rising Power. Routledge, London

Japan Economic Research Centre / JERC (1966) Measures for trade expansion of developing countries. Japan Economic Research Centre, Tokyo

Katada SN (2002) 'Japan and Asian monetary regionalisation: cultivating a new regional leadership after the Asian financial crisis'. Geopolitics 7(1):85-112

Korhonen P (1994) Japan and the Pacific free trade area. Routledge, London

Kurlantzick J (2007) Charm offensive: How China's soft power is transforming the world. Yale University Press, New Haven

Mahathir M (2006) 'Let Asians build their own future regionalism'. Global Asia 1(1):13-15

Okamoto J (2003) Whither free trade agreements? Proliferation, evaluation and multilateralisation. IDEJETRO, Japan

Pyle K (2007) Japan rising: The resurgence of Japanese power and purpose. Public Affairs, New York

Ravenhill J (2003) 'The new bilateralism in the Asia-Pacific'. Third World Quarterly 24(3):299-318

Rose C (2004) Sino-Japanese relations: Facing the past, looking to the future? Routledge, London

Samuels RJ (2007) Securing Japan: Tokyo's grand strategy and the future of East Asia. Cornell University Press, New York

Suzuki S (2007) 'Journey to the West: China debates its great power identity', paper presented at the SinoAustralian Security Relations: Regional Co-operation in an Interdependent World conference, Canberra: Australia National University, October.

Tanaka A (2006) 'Global and regional geo-strategic implications of China’s emergence'. Asian Economic Policy Review 1(1):180-196

Wong J Chan S (2003) 'China - ASEAN free trade agreement: shaping future economic relations'. Asian Survey 43(3):507-526

World Bank (2003) Innovative East Asia: The future of growth. World Bank, Washington DC

Yoshimatsu H (2003) Japan and East Asia in transition: Trade policy, crisis and evolution, and regionalism. Macmillan, Basingstoke

Zhao Q (2004) 'Japan's leadership role in East Asia: co-operation and competition between Japan and China'. Policy and Society 23(1):111-128

Zheng B (2005) 'China's peaceful rise to great power status'. Foreign Affairs 84(5):18-24 